\title{
Susan J. Wendel and David M. Miller, Eds. Torah Ethics and Early Christian Identity
} (Grand Rapids, MI: William B. Eerdmans Publishing Company, 2016), ix +271 pp.

\author{
NATHANIEL DESROSIERS \\ ndesrosiers@stonehill.edu \\ Stonehill College, North Easton, MA 02357
}

The volume is a festschrift in honor of Stephen Westerholm and includes thirteen essays from colleagues and former students. It makes useful contributions by focusing essays around a primary framing question: among early Christians, how did the Law (or Torah) "continue to serve as a reference point for Christbelievers regardless of whether they thought Torah observance was essential?" (p. 2). While no single work can address this complex issue, this book does cover a generous though not exhaustive range of texts and authors. In doing so, the individual essays consider the ongoing influence of Torah as an ethical guide in the teachings of Jesus and the writings of early Christ-followers through the early third century.

The first section, "Torah Ethics in Early Judaism," features two essays that help to frame the discussion of early Christian viewpoints on the Law in the chapters that follow. Anders Runesson begins the volume with his essay "Entering a Synagogue with Paul: First-Century Torah Observance." He argues that at that time there was no single overarching Jewish view of how to observe the Torah. While there was relative fluidity in Torah interpretation, Runesson argues that purity laws were a key defining point for individual communities, which in turn influenced Pauline perspectives on moral purity. In "The Meaning and Function of the Law in Philo and Josephus," John Martens examines the role that the Law played in the formation of Jewish identity for each of these authors. Although both figures emphasize the importance of Torah-based ethics, each has a different perspective on how to incorporate their Jewish views in terms drawn from their Hellenistic thought world. While neither of these essays are ground-breaking interpretations, they may serve as helpful and accessible summaries that could benefit both academic and novice readers.

The second section, "Torah Ethics and the New Testament," is the largest, containing eight essays. Wesley Olmstead, in "Jesus, the Eschatological Perfection of Torah, and the imitation Dei in Matthew," argues that Matthew believes the Torah is still binding on followers of Jesus. However, for the evangelist the Law finds its eschatological fulfillment in Jesus. While this is not a novel claim, 
the chapter is commendable for emphasizing the coherence of Matthew's message about the Law for believers, rather than seeing his views of the Law in tension with his claims about Christ (as is so often the case in scholarship on the topic). S. A. Cummins posits similar conclusions in "Torah, Jesus, and the Kingdom of God in the Gospel of Mark," emphasizing that Mark presents the Torah positively, and that its ethical priority persists through Jesus' life, death, and resurrection. David Miller, in "Reading Law as Prophecy: Torah Ethics in Acts," argues that Luke-Acts describes the Law as a positive model for ethical behavior, albeit a model that is observed differently by Jewish and gentile Christians. A highlight of this section is Adele Reinhartz's "Reproach and Revelation: Ethics in John 11:1-44," in which she argues that Jesus did not always act ethically according to contemporary Jewish precepts. Through a "resistant reading" (p. 94) of the Lazarus story, she suggests that the positive resolution to the story does not justify Jesus' ethical breach. Reinhartz concludes that Torah ethics in John are not explicit but rather inferred by readers historically. Scot McKnight, in "The Law of the Laws: James, Wisdom, and the Law," thoughtfully outlines the deep positive connections between James and the Torah, highlighting the transformation of Jewish legal quotations into Jesus-centered wisdom. However, his argument is more confessional than critical, and is weakened by an insistence that James was the brother of Jesus whose close connection to the teacher enabled him to transmit the "absorbed" teachings of Christ (p. 117-119). In "Questions about Nomos, Answers about Christos: Romans 10:4 in Context," Beverly Roberts Gaventa posits that Paul did not see the Torah as an ethical guide for Jesus-followers. While Gaventa presents a thorough discussion of Paul's words on the Law in Romans, some readers may find her conclusion that Jesus is the replacement of and hence supersedes the Law somewhat unpersuasive. Likewise, Terence Donaldson suggests that the identity-building and identity-affirming role of the Law for Jews has been replaced by Christ in 'Paul, Abraham's Gentile 'Offspring,' and the Torah." Donaldson argues that Paul's Damascus experience led him to see overlap between Jewish Law and natural law, allowing gentiles to become Abraham's seed without circumcision or proselytism. While both Gaventa and Donaldson present thorough discussions of Paul's words on the Torah, some readers may disagree with their conclusions that Paul was arguing for the end of the Law. At minimum, the notion that Jesus is the replacement who supersedes the Law does go against the tide of much recent critical scholarship. The section is concluded with a reprint of "The Conversion of the Imagination: Scripture and Eschatology in 1 Corinthians" by Richard Hays. Hays suggests that Paul sees the Torah as a moral framework for the Corinthian church. Through an eschatological reading of scripture, the Corinthians could come to see themselves as participants in Israel's story.

"Beyond the New Testament," the third section, covers writers from after the New Testament period. It includes three essays. Susan Wendel, in "Torah Obedience and Early Christian Ethical Practices in Justin Martyr," examines Christian apologetic views that describe Christian ethics as both guided by the Law and superior to those of both Jews and Greeks. In "The Law, God, and the Logos: 
Clement and the Alexandrian Tradition," Peter Widdicombe continues this theme by explaining how Clement saw Torah as an ethical guide and a path to virtue, but one that paled in comparison to the ultimate revelation of the Logos in Christ. These two essays are noteworthy because they are thematically connected with earlier essays in the volume delineating the evolution of early Christian views on the Law, which helps to bind the volume together. Finally, Stephen Westerholm, moving beyond the first few centuries, in his concluding essay "Canonical Paul and the Law," suggests that for modern Christians there is a need for a coherent scriptural interpretation of Torah in Christianity. This provides a fitting end to this volume.

Overall, the volume is commendable for its sustained examination of the reasons why Christians ultimately decided not to observe all the commandments of the Law. The volume could be stronger if there were more connections and internal dialogue between the essays, as these would provide greater coherence and opportunities for addressing apparent ancient contradictions and modern disagreements. Also, as indicated above, some contributions are somewhat conservative theologically, which may not appeal to all readers. The book valuably helps readers to decipher the role of the Torah in ancient and modern Christianity. 